\title{
Post-translational modification biology of glutamate receptors and drug addiction
}

\author{
Li-Min Mao', Ming-Lei Guo', Dao-Zhong Jin', Eugene E. Fibuch', Eun Sang Choe ${ }^{1,3}$ and John Q. Wang 1,2* \\ 1 Department of Basic Medical Science, School of Medicine, University of Missouri-Kansas City, Kansas City, MO, USA \\ 2 Department of Anesthesiology, School of Medicine, University of Missouri-Kansas City, Kansas City, MO, USA \\ ${ }^{3}$ Department of Biological Sciences, Pusan National University, Pusan, Korea
}

\section{Edited by:}

Emmanuel Valjent, Université

Montpellier 1 and 2, France

Reviewed by:

Peter Kalivas, University of South Carolina, USA

Karen K. Szumlinski, University of California Santa Barbara, USA

${ }^{*}$ Correspondence:

John Q. Wang, Department of Basic Medical Science, School of Medicine, University of Missouri-Kansas City, 2411 Holmes Street, Kansas City, MO 64108, USA.

e-mail:wangjq@umkc.edu
Post-translational covalent modifications of glutamate receptors remain a hot topic. Early studies have established that this family of receptors, including almost all ionotropic and metabotropic glutamate receptor subtypes, undergoes active phosphorylation at serine, threonine, or tyrosine residues in their intracellular domains. Recent evidence identifies several glutamate receptor subtypes to be direct substrates for palmitoylation at cysteine residues. Other modifications such as ubiquitination and sumoylation at lysine residues also occur to certain glutamate receptors. These modifications are dynamic and reversible in nature and are regulatable by changing synaptic inputs. The regulated modifications significantly impact the receptor in many ways, including interrelated changes in biochemistry (synthesis, subunit assembling, and proteinprotein interactions), subcellular redistribution (trafficking, endocytosis, synaptic delivery, and clustering), and physiology, usually associated with changes in synaptic plasticity. Glutamate receptors are enriched in the striatum and cooperate closely with dopamine to regulate striatal signaling. Emerging evidence shows that modification processes of striatal glutamate receptors are sensitive to addictive drugs, such as psychostimulants (cocaine and amphetamine). Altered modifications are believed to be directly linked to enduring receptor/synaptic plasticity and drugseeking. This review summarizes several major types of modifications of glutamate receptors and analyzes the role of these modifications in striatal signaling and in the pathogenesis of psychostimulant addiction.

Keywords: AMPA, NMDA, mGluR, dopamine, phosphorylation, palmitoylation, ubiquitination, sumoylation

\section{INTRODUCTION}

The neurotransmitter l-glutamate (glutamate) interacts with specific ionotropic glutamate receptors (iGluR) or metabotropic glutamate receptors (mGluR; Dingledine et al., 1999; Cull-Candy et al., 2001). The former are the ligand-gated ion channel and are classified into $N$-methyl-D-aspartate receptors (NMDAR), $\alpha$-amino-3hydroxy-5-methylisoxazole-4-propionic acid receptors (AMPAR), and kainate receptors. The latter are the $G$ protein-coupled receptor. Through various $G$ proteins, they connect to multiple second messenger systems. There are three functional groups of mGluRs (group I-III) classified from eight subtypes (mGluR1-8; Conn and Pin, 1997). Group I mGluRs (mGluR $1 / 5$ subtypes) are positively coupled to phospholipase $C \beta 1$ through Goq proteins. Activation of mGluR1/5 increases phosphoinositol hydrolysis, resulting in intracellular $\mathrm{Ca}^{2+}$ release and protein kinase C (PKC) activation (Conn and Pin, 1997). Both group II (mGluR2/3) and group III (mGluR4/6/7/8) receptors are negatively coupled to adenylyl cyclase through $\mathrm{G} \alpha \mathrm{i} / \mathrm{o}$ proteins. Their activation reduces cAMP formation and inhibits protein kinase A (PKA).

Diverse post-translational modifications occur at intracellular domains of glutamate receptors and represent regulatory mechanisms for controlling many properties of modified receptors. Early extensive studies have established a phosphorylation modification of both iGluRs and mGluRs (Swope et al., 1999; Wang et al., 2006). By targeting specific amino acids (serine, threonine, and tyrosine), multiple protein kinases and phosphatases control phosphorylation levels of glutamate receptors. Recent work identifies fatty acylation, such as palmitoylation, as another important type of modification at cysteine residues. Lysine residues may also be modified by the enzymatic cascades known as ubiquitination and sumoylation. All these modifications are noticeably physiological events and sensitive to changing synaptic inputs. They are labile, dynamic and reversible in nature, unlike other modifications, such as prenylation, farnesylation, and geranylation, which are semi-permanent and serve to anchor proteins to membranes. Thus, these reversible modifications are believed to activity-dependently regulate and assure normal expression and function of glutamate receptors. As such, malfunction of these modifications is frequently associated with the pathogenesis of various neuropsychiatric disorders.

The striatum, i.e., the dorsal caudate putamen and ventral nucleus accumbens (NAc), is a central structure in reward circuits implicated in drug addiction. This region is enriched with glutamatergic innervation and glutamate receptors. The accumulated data support the role of striatal glutamatergic transmission in drug addiction (Tzschentke and Schmidt, 2003; Hyman et al., 2006). Recently, emerging evidence links post-translational modifications of glutamate receptors to excitatory synaptic plasticity and drug-seeking behavior. Generally, modification processes of striatal glutamate receptors are sensitive to addictive drugs such as the psychostimulants (cocaine and amphetamine). Altered modifications 
contribute to enduring receptor plasticity and the addictive properties of drugs. This review will primarily discuss post-translational modifications of glutamate receptor and their associations with drug action, while roles of individual glutamate receptors in drug addiction have been thoroughly reviewed elsewhere (Bird and Lawrence, 2009; Kalivas, 2009; Bowers et al., 2010; Moussawi and Kalivas, 2010; Schmidt and Pierce, 2010). We will focus on several major types of modifications appreciated recently, including phosphorylation, palmitoylation, ubiquitination, and sumoylation, based on the available data linking them to drug addiction. Of note, in addition to addiction, abnormalities in the modifications of glutamate receptors can be observed in many other disease models, such as schizophrenia (Li et al., 2009), anxiety (Delawary et al., 2010), and Parkinson's disease (Ba et al., 2006).

\section{PHOSPHORYLATION OF GLUTAMATE RECEPTORS AT SERINE/ THREONINE \\ $\alpha$-AMINO-3-HYDROXY-5-METHYLISOXAZOLE-4-PROPIONIC ACID RECEPTORS}

Phosphorylation of AMPARs at serine/threonine has been well established (Wang et al., 2006). Most AMPARs become functional upon a heteromeric assembly of four subunits (GluA1-4 or GluR14). A tetrameric structure seems to be prototypic and is assembled by dimer-of-dimers of GluA2 and either GluA1, GluA3, or GluA4. As a membrane-bound receptor, four subunit proteins share the same conformation in the plasma membrane: four transmembrane domains (TMD; M1-4) with an extracellular N-terminus and an intracellular C-terminus. C-termini are variable in length among subunits and are intracellular domains for protein-protein interactions and serine/threonine phosphorylation (Carvalho et al., 2000). To date, the GluA1 C-terminus has four identified phosphorylation sites at serine 818 (S818), S831, threonine 840 (T840), and S845 (Roche et al., 1996; Barria et al., 1997; Mammen et al., 1997; Table 1). Other subunits are also similarly phosphorylated at their C-terminal serine and/or threonine residues (Chung et al., 2000; Wang et al., 2006). S818 is phosphorylated by PKC (Boehm et al., 2006) and S831 by both PKC and $\mathrm{Ca}^{2+} /$ calmodulin-dependent protein kinase II (CaMKII; Roche et al., 1996; Barria et al., 1997; Mammen et al., 1997). T840 is not a substrate of the common kinases such as PKA, PKC, or CaMKII, but it appears to be a substrate of p70S6 kinase (Delgado et al., 2007). Finally, S845 is specific for PKA-mediated phosphorylation (Roche et al., 1996).

Phosphorylation is one of the post-translational modifications that are labile and reversible. In fact, AMPAR phosphorylation is subject to the vigorous regulation by synaptic signals. Regulated phosphorylation in turn adjusts expression, distribution (synaptic delivery) and function of the receptor usually in a site-specific fashion. Acute phosphorylation of GluA1 S818 by PKC promoted GluA1 synaptic incorporation and an activity-dependent form of synaptic plasticity, long-term potentiation (LTP; Boehm et al., 2006). PKC/CaMKII-sensitive S831 and PKA-sensitive S845 phosphorylation potentiated AMPAR currents and augmented LTP (Roche et al., 1996; Derkach et al., 1999; Banke et al., 2000). Activity-driven PKA phosphorylation of S845 also drove AMPARs to synapses, which was necessary for LTP (Estaban et al., 2003). T840 is dephosphorylated by NMDAR signals, which is implicated in long-term depression (LTD; Delgado et al., 2007).
AMPARs are densely expressed in striatal medium spiny output neurons and certain types of interneurons (Martin et al., 1993; Bernard et al., 1997). These postsynaptic receptors are present in the perikarya, dendrites, and spines with a significant amount of extrasynaptic receptors on these subcellular specializations. The site-specific phosphorylation of striatal GluAl subunits in response to drug exposure has been extensively studied. It is apparent that dopamine is a strong regulator of their phosphorylation. By stimulating D1 dopamine receptors and associated cAMP/ PKA pathways, the D1 agonist and psychostimulants (cocaine and amphetamines) increased GluA1 phosphorylation preferentially at S845 in striatal neurons (Price et al., 1999; Snyder et al., 2000; Chao et al., 2002). This facilitated surface/synaptic delivery of AMPARs and potentiated efficacy and strength of excitatory synapses (Price et al., 1999; Mangiavacchi and Wolf, 2004; Swayze et al., 2004). In contrast to D1 signals, the D2 receptor inhibits $\mathrm{S} 845$ phosphorylation (Hakansson et al., 2006).

Plastic changes in AMPAR phosphorylation may constitute an important layer of underlying mechanisms for receptor plasticity and drug addiction. Several studies in chronic drug administration models (passive repeated administration or operant selfadministration) have established an association (correlation) between AMPAR phosphorylation and enduring behavioral plasticity (behavioral sensitization and more significantly drugseeking behavior), although a causal link between them remains to be proven experimentally. For instance, cocaine-sensitized or heroin self-administering rodents were associated with increased phosphorylation at S845 in the NAc (Zhang et al., 2007; Edwards et al., 2009; Chen et al., 2010; but Mattson et al., 2005; Chen and Manev, 2010) and at S831 in the CPu (Kim et al., 2009). Increased accumbens shell S831 phosphorylation was seen in animals showing reinstatement of cocaine-seeking (Anderson et al., 2008). In addition to GluA1, elevated GluA2 S880 phosphorylation in the NAc was related to reinstatement of cocaine-seeking (Famous et al., 2008). These results imply a phosphorylation-dependent mechanism for AMPAR plasticity and drug-seeking. S845/S831 phosphorylation is likely to be upregulated to increase surface AMPAR expression and thereby enhance AMPAR transmission related to behavioral plasticity (Boudreau and Wolf, 2005; Conrad et al., 2008). However, self-administration of cocaine induced lesser S845 phosphorylation in the striatum as compared to acute cocaine injection, establishing a tolerance of S845 phosphorylation in response to chronic cocaine (Edwards et al., 2007). This tolerance may reflect a downregulated GluA1 function in accumbens neurons and may contribute to cocaine sensitization and cocaineseeking behavior (Sutton et al., 2003; Bachtell et al., 2008). These results underscore the complexity of AMPARs' roles in drug action. Distinct roles of the receptor may derive from differences in subsets of synapses, subpopulations of projection and interneurons, subdivisions of the NAc (core versus shell), early or late withdrawal times and addiction stages, different administration/test regimens, and types of behavior surveyed.

\section{N-METHYL-D-ASPARTATE RECEPTORS}

Like AMPARs, NMDARs are tetrameric assemblies of two obligatory GluN1 subunits and two modulatory GluN2 subunits (Dingledine et al., 1999; Cull-Candy et al., 2001). The difference 
Table 1 | Post-translational modifications of glutamate receptors.

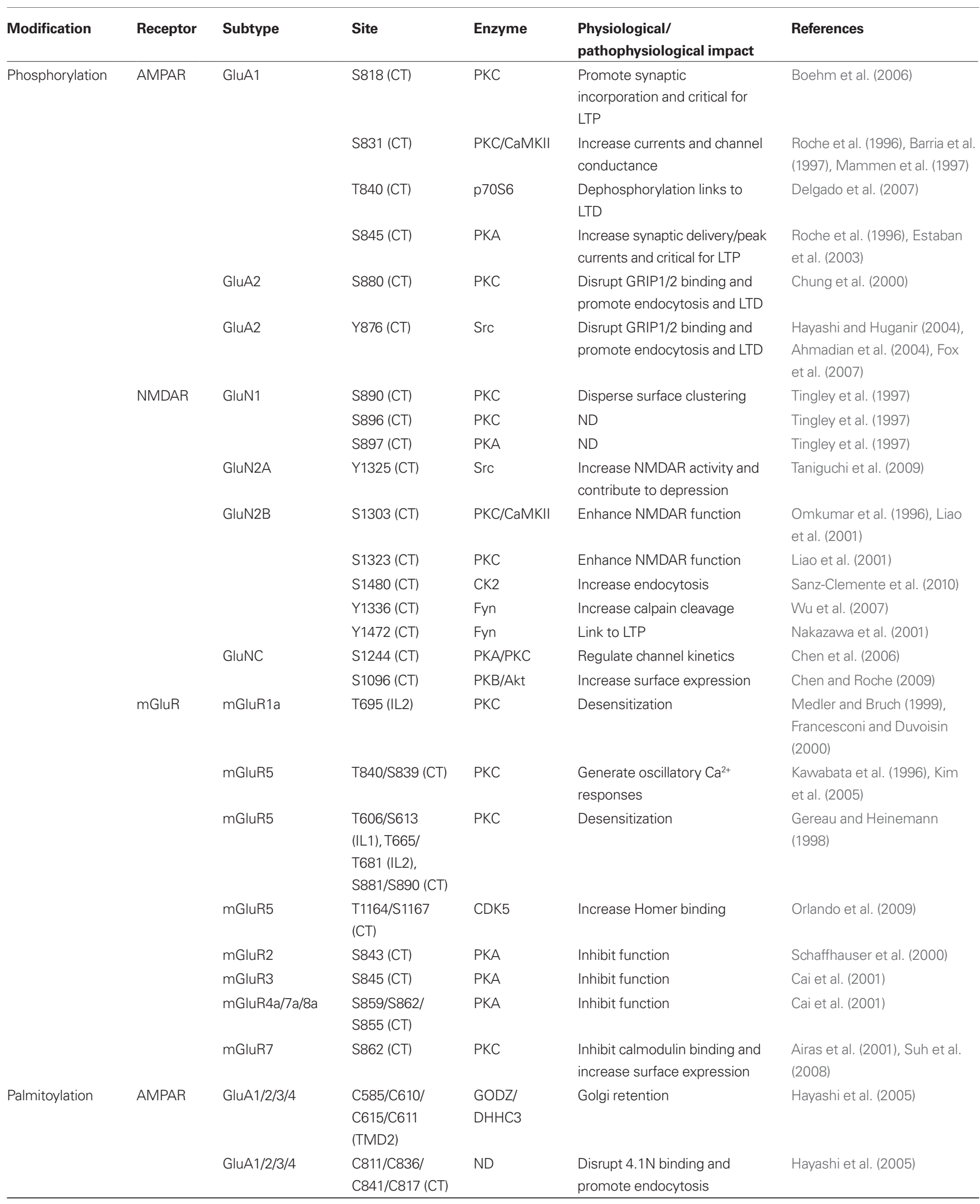


Table 1 | Continued

\begin{tabular}{|c|c|c|c|c|c|c|}
\hline Modification & Receptor & Subtype & Site & Enzyme & $\begin{array}{l}\text { Physiological/ } \\
\text { pathophysiological impact }\end{array}$ & References \\
\hline & NMDAR & GluN2A & $\begin{array}{l}\text { C848/C853/ } \\
\text { C870 (CT, 1st } \\
\text { cluster) }\end{array}$ & $\begin{array}{l}\text { GODZ/ } \\
\text { DHHC3 }\end{array}$ & $\begin{array}{l}\text { Increase tyrosine } \\
\text { phosphorylation and surface } \\
\text { expression }\end{array}$ & Hayashi et al. (2009) \\
\hline & & GluN2A & $\begin{array}{l}\text { C1214/C1217/ } \\
\text { C1236/C1239 } \\
\text { (CT, 2nd cluster) }\end{array}$ & $\begin{array}{l}\text { GODZI } \\
\text { DHHC3 }\end{array}$ & Golgi retention & Hayashi et al. (2009) \\
\hline & & GluN2B & $\begin{array}{l}\text { C848/C854/ } \\
\text { C871 (CT, 1st } \\
\text { cluster) }\end{array}$ & $\begin{array}{l}\text { GODZ/ } \\
\text { DHHC3 }\end{array}$ & $\begin{array}{l}\text { Increase tyrosine } \\
\text { phosphorylation and surface } \\
\text { expression }\end{array}$ & Hayashi et al. (2009) \\
\hline & & GluN2B & $\begin{array}{l}\text { C1215/C1218/ } \\
\text { C1239/C1242/ } \\
\text { C1245 (CT, 2nd } \\
\text { cluster) }\end{array}$ & $\begin{array}{l}\text { GODZ/ } \\
\text { DHHC3 }\end{array}$ & Golgi retention & Hayashi et al. (2009) \\
\hline & mGluR & mGluR4 & ND & ND & ND & Alaluf et al. (1995) \\
\hline \multirow[t]{4}{*}{ Ubiquitination } & NMDAR & GluN1 & ND & ND & Decrease expression & $\begin{array}{l}\text { Ratnam and Teichberg (2005), } \\
\text { Kato et al. (2005) }\end{array}$ \\
\hline & & GluN2B & ND & $\begin{array}{l}\text { Mind } \\
\text { bomb-2 }\end{array}$ & Decrease NMDAR activity & Jurd et al. (2008) \\
\hline & Kainate & GluK6 & $\begin{array}{l}\text { ND (I884 is } \\
\text { critical for } \\
\text { binding } \\
\text { enzyme) }\end{array}$ & ND & Decrease surface expression & Salinas et al. (2006) \\
\hline & mGluR & mGluR1a/5 & ND & Siah1A & Decrease expression & Moriyoshi et al. (2004) \\
\hline
\end{tabular}

ND, not determined; IL1, intracellular loop 1; IL2, intracellular loop 2; CT, C-terminus. See text for other abbreviations.

in GluN2 subunit compositions (GluN2A-D) largely determines the distinct gating and pharmacology of the channel. As a transmembrane receptor, each NMDAR subunit shares an extracellular N-terminus and an intracellular C-terminus. The C-terminal region is large especially for GluN2A and GluN2B, which provides a spacious area for protein kinase interactions and serine/threonine phosphorylation. Indeed, three NMDAR subunits (GluN1, GluN2B, and GluN2C) have been found to undergo active phosphorylation at distinct serine/threonine sites. Within the GluN1 C-terminal domain, PKC phosphorylates S890 and S896 (Tingley et al., 1997). An S896-neighboring site, S897, is a substrate of PKA (Tingley et al., 1997). GluN2B S1303 is subject to phosphorylation by CaMKII (Omkumar et al., 1996). PKC may be another kinase for this site as well as $\mathrm{S} 1323$ (Liao et al., 2001). A more recently identified site on the GluN2B C-terminus, S1480, is within a PDZ-binding domain and is sensitive to casein kinase (CK2; Sanz-Clemente et al., 2010). The GluN2C C-terminus is phosphorylated at S1244 by both PKA and PKC (Chen et al., 2006) and at S1096 by protein kinase B (PKB)/Akt (Chen and Roche, 2009). The phosphorylation level at these sites has a significant impact on some key properties of the receptor. PKC phosphorylation of S890 dispersed the surface clusters of GluN1 (Tingley et al., 1997). PKC-sensitive phosphorylation of GluN1 and GluN2B (S1303 and S1323) enhanced NMDAR function (Hisatsune et al., 1997; Liao et al., 2001). CK2 phosphorylation of GluN2B S1480 drove GluN2B endocytosis and facilitated developmental switch from GluN2B to GluN2A at synapses (SanzClemente et al., 2010). PKB phosphorylation of GluN2C S1096 enhanced surface expression of GluN2C-containing NMDARs and supported neuronal survival (Chen and Roche, 2009).

GluN2A and GluN2B are the predominant GluN2 subunits in the striatum. Major tetrameric subtypes of NMDARs in this region are therefore thought to be $2 \mathrm{GluN1} / 2 \mathrm{GluN} 2 \mathrm{~A}, 2 \mathrm{GluN} 1 / 2 \mathrm{GluN} 2 \mathrm{~B}$, or $2 \mathrm{GluN} 1 / 1 \mathrm{GluN} 2 \mathrm{~A} / 1 \mathrm{GluN} 2 \mathrm{~B}$, in addition to some binary subtypes containing one GluN1 and one GluN2A or GluN2B subunit (Dunah et al., 2000; Dunah and Standaert, 2003). Both striatonigral and striatopallidal projection neurons and cholinergic interneurons express a high level of NMDARs (Landwehrmeyer et al., 1995; Chen et al., 1996). Most GluN1/GluN2A receptors are incorporated into synapses, while GluN1/GluN2B receptors are present at both synaptic and extrasynaptic sites (Tovar and Westbrook, 1999). 
Enriched expression of NMDARs in the striatum implies their roles in drug action and provides an opportunity to investigate adaptive changes in the receptor phosphorylation in response to psychostimulants. Acute amphetamine increased GluN1 S896 phosphorylation primarily in D1 receptor-bearing striatonigral neurons (Liu et al., 2004). Direct stimulation of D1 receptors with D1 agonists enhanced PKA-sensitive GluN1 S897 phosphorylation through the D1/cAMP/PKA pathway (Dudman et al., 2003). The enhanced S897 phosphorylation seems to lead to a cytosolic $\mathrm{Ca}^{2+}$ rise, which synergizes with the cAMP/PKA signals to activate the transcription factor $\mathrm{Ca}^{2+} / \mathrm{cAMP}$ response element binding protein (CREB) to facilitate gene expression. These results show the ability of psychostimulants to modify NMDAR phosphorylation. Through modifying the receptor, stimulants regulate gene expression and construct transcription-dependent neuroadaptations essential for long-lasting drug action.

In addition to the D1 receptor, the D2 receptor is involved in the regulation of NMDAR phosphorylation (Liu et al., 2006). A single dose of cocaine induced a heteroreceptor complex formation between D2 receptors and GluN2B in D2 receptor-bearing striatopallidal neurons. The interaction of D2 receptors with GluN2B disrupted the association of CaMKII with GluN2B, thereby reducing phosphorylation at the CaMKII-sensitive site S1303 and inhibiting NMDAR currents. Behaviorally, this phosphorylation-involved D2-GluN2B interaction suppressed the inhibitory indirect pathway to promote a full motor response to cocaine.

Chronic cocaine reduced GluN1 S896 phosphorylation in the rat frontal cortex at $24 \mathrm{~h}$, although not 14 days, of withdrawal (Loftis and Janowsky, 2002). However, cocaine self-administration had a minimal influence over S896 phosphorylation in the monkey striatum (Hemby et al., 2005). Acute, repeated, and self administration of cocaine increased GluN1 S897 phosphorylation in the rat striatum (Edwards et al., 2007). These results demonstrate that in the striatum at least $\mathrm{S} 897$ is a sensitive site modified by cocaine. Future studies are needed to elucidate how S897 phosphorylation mediates NMDAR plasticity and drug craving.

\section{METABOTROPIC GLUTAMATE RECEPTORS}

The mGluR is an equally sensitive substrate for phosphorylation and PKC's roles in mGluR phosphorylation have been the most extensively studied (Kim et al., 2008; Mao et al., 2008). The long form group I mGluRs ( $1 \mathrm{a}, 5 \mathrm{a}$, and $5 \mathrm{~b}$ ) have a characteristically large C-terminal tail. A threonine residue (T840) or an adjacent S839 in the proximal region of mGluR5a C-terminus undergoes PKCmediated phosphorylation (Kawabata et al., 1996; Kim et al., 2005). This single site phosphorylation determines the pattern of $\mathrm{Ca}^{2+}$ responses to mGluR5 stimulation (Kawabata et al., 1996; Uchino et al., 2004). PKC also possibly phosphorylates other serine/threonine sites (T606, S613, T665, T681, S881, and S890 for mGluR5a; T695 for mGluR1a). Phosphorylation at these sites is involved in rapid desensitization of the receptor (Gereau and Heinemann, 1998; Medler and Bruch, 1999; Francesconi and Duvoisin, 2000). In addition to PKC, cyclin-dependent kinase 5 (CDK5) phosphorylates two residues (T1164/S1167) within the domain of mGluR1/5 C-termini that interacts with the scaffold protein Homer (Orlando et al., 2009). This phosphorylation increased the binding of the receptor to Homer.
Group II/III mGluRs are also phosphorylated at serine/threonine. PKA phosphorylates mGluR2 S843, mGluR3 S845, mGluR4a S859, mGluR7a S862, and mGluR8a S855 on the C-terminal tail to inhibit their function as presynaptic receptors (Schaffhauser et al., 2000; Cai et al., 2001). PKC phosphorylates a conserved site (S862) on mGluR7 C-termini to inhibit calmodulin binding in vitro (Airas et al., 2001). In addition, mGluR7 S862 phosphorylation, in combination with the binding of the PDZ domain-containing protein PICK1, stabilized surface mGluR7 expression in vivo (Suh et al., 2008). At present, studies on the regulation of mGluR phosphorylation by addictive drugs are limited, partially due to the lack of phospho- and site-specific antibodies. One study revealed that relative serine phosphorylation of the mGluR2/3 monomer was elevated in both the NAc and prefrontal cortex after repeated cocaine, which was associated with an enduring reduction of mGluR2/3 function in inhibiting glutamate release (Xi et al., 2002). How phosphorylation modifications of mGluRs precisely contribute to drug-induced mGluR plasticity and drug-seeking behavior remains an interesting topic in future studies.

\section{PHOSPHORYLATION OF GLUTAMATE RECEPTORS AT TYROSINE}

In addition to serine and threonine, tyrosine is another phosphorylation site on glutamate receptors. GluA1 and GluA2 intracellular domains are tyrosine-phosporylated (Hayashi and Huganir, 2004; Wu et al., 2004). The distal region of the GluA2 $\mathrm{C}$-terminus possesses multiple tyrosine residues. Non-receptor Src family tyrosine kinases phosphorylate tyrosine 876 (Y876; Hayashi and Huganir, 2004), the last tyrosine residue near the end of C-terminus that lies within the PDZ ligand motif. Y876 phosphorylation disrupted the association of GluA2 with the PDZ domain-containing proteins, such as glutamate receptor interacting proteins 1 and 2 (GRIP1/2), and thereby promoted endocytosis of GluA2 (Hayashi and Huganir, 2004) and LTD (Ahmadian et al., 2004; Fox et al., 2007). GluN2, although not GluN1, subunits are also tyrosine-phosphorylated in their C-termini (Lau and Huganir, 1995; Menegoz et al., 1995; Dunah et al., 2000). Both Src-family tyrosine kinases (Src and Fyn) and Src-independent tyrosine kinases can carry out the phosphorylation (Suzuki and Okumura-Noji, 1995; Zheng et al., 1998; $\mathrm{Xu}$ et al., 2009). Multiple tyrosine residues (7 of 25, including 1252, 1336, and 1472) within the GluN2B C-terminus are responsive to phosphorylation. Y1472 seems to be a major site (Nakazawa et al., 2001) comparable to a major site (Y1325) on GluN2A (Taniguchi et al., 2009). GluN2 phosphorylation usually enhances NMDAR-mediated currents and NMDAR-dependent LTP via mechanisms involving the regulation of trafficking and protein-protein interactions (Wang and Salter, 1994; Lau and Huganir, 1995; Rostas et al., 1996; Dunah et al., 2004). Moreover, the influence of tyrosine phosphorylation can be site-selective. Y1472 and Y1336 phosphorylation was associated with enrichment of synaptic and extrasynaptic NMDARs, respectively (Goebel-Goody et al., 2009). Fyn-mediated Y1336 phosphorylation site-dependently controlled GluN2B cleavage by calpain (Wu et al., 2007). Regarding mGluRs, mGluR5 was abundantly tyrosine-phosphorylated in striatal neurons in vivo, based on pharmacological studies with tyrosine kinase or phosphatase 
inhibitors and immunoprecipitation experiments with antiphosphotyrosine antibodies (Orlando et al., 2002), although accurate site(s) among a few tyrosine residues on the mGluR5 C-terminus have not been determined.

D1 receptor signals increased synaptic delivery of tyrosinephosphorylated GluN2A and GluN2B in striatal neurons (Dunah and Standaert, 2001). This event is tyrosine phosphorylationdependent because the tyrosine kinase inhibitor genistein blocked it and the phosphatase inhibitor pervanadate mimicked D1 signals to induce the delivery. In cultured neurons, D1 receptor stimulation increased GluN2B phosphorylation at Y1472, which increased surface expression of GluN2B/NMDARs in prefrontal cortical neurons (Guo and Wolf, 2008) and facilitated the clustering of GluN2B along the dendritic spine shaft in striatal neurons (Hallett et al., 2006). In addition to D1 signals, brain-derived neurotrophic factor (BDNF) rapidly increased Fyn-sensitive Y1472 phosphorylation and NMDAR activity (Xu et al., 2006). In studies with addictive drugs, acute cocaine increased Src-dependent tyrosine phosphorylation of GluN2A, leading to elevated NMDAR expression and activity in the ventral tegmental area (Schumann et al., 2009). Repeated administration of alcohol elevated Fyn activity, Y1472 phosphorylation, and GluN2B-NMDAR function in the dorsomedial striatum (Wang et al., 2010). Inhibition of Src family tyrosine kinases decreased self-administration of alcohol (Wang et al., 2010). Thus, plastic changes in Y1472 phosphorylation can be a critical element linking NMDAR plasticity to drug-taking. In general, available data indicate the linkage between tyrosine phosphorylation of NMDAR GluN2 and drug action. As for AMPARs and mGluRs, little is known about how tyrosine phosphorylation of these receptors responds to drugs and the role of tyrosine phosphorylation might play in determining drug-induced receptor and behavioral adaptations.

\section{PALMITOYLATION OF GLUTAMATE RECEPTORS AT CYSTEINE}

Like phosphorylation, fatty acylation, such as palmitoylation, is another important type of modification. Palmitoylation is the covalent attachment of a 16 carbon saturated fatty acid, palmitate (palmitic acid), to a cysteine residue most commonly via a thioester bond. This process is an enzymatic event and is catalyzed by a family of palmitoyl acyltransferases (PATs). All PATs contain a signature Asp-His-His-Cys (DHHC) Cys-rich domain conserved from yeast to mammals (Planey and Zacharias, 2009). At least 23 mammalian DHHC-containing PATs (DHHC1-23) have been identified. These PATs have distinct substrate selectivity, although it is unclear yet if there exists a consensus PAT palmitoylation motif (Planey and Zacharias, 2009). As one type of lipidation, palmitoylation increases the lipophilicity or hydrophobicity of modified proteins. As such, it often results in an altered protein affinity for the plasma membrane, leading to protein trafficking from one membrane system to another. Additionally, palmitoylation can alter interactions of modified proteins with their binding partners, thereby regulating their subcellular distribution and function. Like phosphorylation and unlike other forms of lipidation, palmitoylation (the thioester bond) is labile and reversible. This nature situates it well as an activity-dependent regulator of synaptic proteins, including glutamate receptors. All four AMPAR subunits (GluA1-4) are palmitoylated constitutively in transfected
HEK 293T cells, cultured cortical neurons, and striatal neurons in vivo (Hayashi et al., 2005; Van Dolah et al., 2011). Two conserved cysteine residues on these subunits undergo reliable palmitoylation: one within C-terminal regions (GluA1-C811, GluA2-C836, GluA3-C841, and GluA4-C817) and another within the TMD 2 (GluA1-C585, GluA2-C610, GluA3-C615, and GluA4-C611; Hayashi et al., 2005). These sites are surrounded by basic and hydrophobic residues. They are adjacent to TMD, consistent with a pattern of palmitoylation for transmembrane proteins, i.e., palmitoylation at intracellular cysteines near TMD (El-Husseini and Bredt, 2002). Regarding potential PAT subtypes catalyzing AMPAR palmitoylation, a Golgi-specific protein with a DHHC zinc finger domain (GODZ, also known as DHHC3) promoted the palmitoylation on the TMD 2 site, while the exact PAT subtype for the C-terminal site remains to be identified (Hayashi et al., 2005). In addition to DHHC3, a dendritically localized DHHC2 activitydependently translocated to the postsynaptic density (PSD) to induce rapid palmitoylation of PSD-95 in cultured hippocampal neurons (Noritake et al., 2009).

As aforementioned, palmitoylation controls redistribution of modified proteins usually in an activity-sensitive fashion. According to Hayashi et al. (2005), GODZ increases palmitoylation of AMPARs on the TMD 2 site and retains the receptor in the Golgi apparatus. In contrast, depalmitoylation releases the receptor from the Golgi for surface delivery. On the C-terminal site, palmitoylation disrupts the interaction of receptors with $4.1 \mathrm{~N}$, a synapse-enriched cytoskeletal protein that stabilizes surface AMPAR expression, and enhances susceptibility to agonist-induced internalization trafficking. Depalmitoylation increases the receptor affinity for $4.1 \mathrm{~N}$ and stabilizes the receptor on surface membrane. Apparently, the balance of palmitoylation and depalmitoylation is regulated by synaptic activity. Such regulatable balance determines subcellular distribution of the receptor.

$N$-methyl-D-aspartate receptors GluN2A and GluN2B subunits have two distinct clusters of palmitoylation sites in their C-terminal regions (Hayashi et al., 2009). The first cluster is proximal to membrane (GluN2A: C848, C853, and C870; GluN2B: C849, C854, and C871). Palmitoylation of these sites increased tyrosine phosphorylation, leading to enhanced surface expression of the receptor. The second cluster resides in the middle of C terminus (GluN2A: C1214, C1217, C1236, and C1239; GluN2B: C1215, C1218, C1239, C1242, and $\mathrm{C} 1245)$. Their palmitoylation caused receptors to accumulate in the Golgi apparatus and reduced receptor surface expression. Recombinant kainate receptor GluK6 subunits expressed in HEK cells are palmitoylated at C-terminal C827 and C840 (Pickering et al., 1995). mGluR palmitoylation has been less extensively studied. Available data show that mGluR4 but not mGluR $1 \alpha$ is palmitoylated in heterologous cells transfected with these subtypes (Alaluf et al., 1995; Pickering et al., 1995). Little is known about the palmitoylation status of endogenous mGluRs in neurons.

Palmitate is the most abundant fatty acid in the brain. Thus, inducible, regulatable, and reversible palmitoylation could be a common mechanism for regulating normal glutamate receptors and excitatory synapses. An attractive speculation is that glutamate receptor palmitoylation could also be plastic in response to drug exposure and is thus involved in enduring synaptic and behavioral plasticity. At present, the study linking palmitoylation to addiction 
is limited partially due to the lack of palmito- and site-specific antibodies that are needed to detect site-specific palmitoylation responses to drugs in in vivo adult rodent brains. Nevertheless, one recent study shows that palmitoylation of AMPARs is subject to the regulation by a psychostimulant (Van Dolah et al., 2011). Acute cocaine induced a transient and reversible increase in overall GluA1 and GluA3 palmitoylation in the rat NAc, while cocaine did not affect GluA2 and GluA4 palmitoylation. This increase was correlated well with a temporary loss of surface GluA1/3. Pharmacological inhibition of protein palmitoylation reversed the loss of local GluA1/3. Thus, the increased palmitoylation appears to cause reduction of GluA1/3 surface expression, probably via an enhanced internalization rate due to disrupted interactions with the surface-stabilizing protein 4.1N (see above). Noticeably, AMPAR palmitoylation contributes to the regulation of behavioral sensitivity to cocaine. Since blocking AMPAR palmitoylation responses to cocaine augmented motor responses to the drug, the induced palmitoylation may downregulate surface AMPAR expression to prevent motor overstimulation. It will be interesting to explore how palmitoylation of AMPARs responds to chronic drug administration and whether palmitoylation is another modification that needs to be investigated for elucidating mechanisms underlying AMPAR plasticity and drug addiction.

\section{UBIOUITINATION OF GLUTAMATE RECEPTORS AT LYSINE}

Ubiquitination is a stepwise enzymatic process carried out by a set of three enzymes. Initially, a small regulatory protein ubiquitin is activated by the ubiquitin-activating enzyme (E1). Active ubiquitin is then transferred to the ubiquitin-conjugating enzyme (E2). Finally, the C-terminal glycine of ubiquitin recognizes and binds the lysine in the modified protein via the ubiquitin-protein ligase (E3). The whole process can be repeated until a short chain of ubiquitin is formed (polyubiquitination) to target the modified protein to degradation by proteasomes. The ubiquitin-proteasome system (UPS) serves as a fundamental mechanism for the regulation of protein expression and function. Increasing evidence supports its role as an important regulator of synaptic plasticity (Yi and Ehlers, 2005). To date, a subset of synaptic scaffolds, including Shank, guanylate kinase-associated protein (GKAP) and A-kinase anchoring protein (AKAP), have been found to be polyubiquitinated in cultured hippocampal or cortical neurons (Ehlers, 2003) or in the rat striatum in vivo (Mao et al., 2009). PSD-95 may arguably be ubiquitinated (Colledge et al., 2003; Bingol and Schuman, 2004). Among glutamate receptor subtypes surveyed, there is evidence showing that GluN1 and GluN2B could be the direct targets of ubiquitin in heterologous cells or in cultured neurons, although results are not always consistent (Ehlers, 2003; Kato et al., 2005; Ratnam and Teichberg, 2005; Jurd et al., 2008). GluK6 is ubiquitinated (Salinas et al., 2006). Group I mGluRs (mGluR1 $\alpha$ and mGluR5) can also undergo polyubiquitination in heterologous cells via a specific E3 ligase, seven in absentia homolog 1A (Siah1A; Moriyoshi et al., 2004). Multiple lysine sites at mGluR5 intracellular loops and the C-terminal tail are among the sites ubiquitinated, although the exact sites remain to be identified. Functionally, polyubiquitination determines the degradation rate and expression level of the receptor, while mono-ubiquitination may carry out some nonproteolytic roles, including the regulation of receptor endocytosis.
Given the regulatory role of ubiquitination and degradation in synaptic plasticity, it is intriguing to explore whether ubiquitination is directly involved in the remodeling of excitatory synapses and behavioral plasticity in response to drug exposure. Mao et al. (2009) have recently found that chronic amphetamine administration enhanced ubiquitin conjugation to synaptic proteins in the rat striatum. The specific substrates sensitive to the drug in their ubiquitination include Shank and GKAP. Since these two scaffold proteins are known to anchor PSD-95 and PSD-95-linked GluN2B to the PSD microdomain, the ubiquitination-dependent removal of Shank/GKAP may have a significant impact on the stability of PSD-95/GluN2B, even though PSD-95/GluN2B are not direct ubiquitin targets. In fact, striatal PSD-95 (Yao et al., 2004) and GluN2B proteins were reduced in parallel with reduced levels of Shank and GKAP (Mao et al., 2009). Inhibition of proteasomes reversed the reduction of all four proteins (Shank, GKAP, PSD-95, and GluN2B) in the striatum of amphetamine-treated rats. Destabilization of GluN2B through this mechanism further translates to the inhibitory modulation of synaptic plasticity in the form of LTD at cortico-accumbal glutamatergic synapses and contributes to behavioral sensitization. These data link ubiquitination to glutamate receptor plasticity in relation to drug action and pave the way for further studies to characterize this new layer of mechanisms.

NAC-1 is a transcription factor in brain cells and is localized in the nucleus. Its mRNA levels were increased in the rat NAc 3 weeks after chronic cocaine self-administration (Cha et al., 1997). NAC-1 is deemed to play an important role in modifying long-term behavioral effects of cocaine (Mackler et al., 2000). Interestingly, NAC-1 forms complexes with proteins in the UPS (Shen et al., 2007). NAC- 1 and the proteasome were cotranslocated from the nucleus into dendritic spines and the PSD microdomain when synaptic activity was disinhibited by bicuculline (Shen et al., 2007). Thus, NAC-1 has a potential to modify drug-induced synaptic plasticity via recruiting the UPS into synaptic sites.

\section{SUMOYLATION OF GLUTAMATE RECEPTORS AT LYSINE}

Analogous to ubiquitination, sumoylation is a sequential enzymatic modification of proteins at lysine residues. Through a defined cascade involving three enzymes (E1-3), small ubiquitin-like modifier or SUMO proteins, a family of small proteins similar to ubiquitin, are covalently attached to and detached from target proteins (GeissFriedlander and Melchior, 2007; Heun, 2007). Specifically, at the final step, the C-terminal glycine of SUMO forms an isopeptide bond with an acceptor lysine on the target protein. In contrast to ubiquitin, SUMO is not used to tag proteins for degradation. It instead has diverse functions most frequently linked to protein protection from ubiquitination (stability), protein-protein interactions, cytosol-nuclear transport, and transcriptional regulation (Zhao, 2007). These functions are directly derived from the sumoylation-induced changes in trafficking/subcellular redistribution and binding properties of modified proteins with their interactors. Typically, sumoylation is carried out at a consensus motif. Most modified proteins contain the tetrapeptide consensus motif $\psi-\mathrm{K}-\mathrm{x}-\mathrm{D} / \mathrm{E}$ where $\psi$ is a hydrophobic residue, $\mathrm{K}$ is the lysine conjugated to SUMO, $\mathrm{x}$ is any amino acid, $\mathrm{D}$ or $\mathrm{E}$ is an acidic residue. Free online engines, such as SUMOplot or SUMOsp (Ren et al., 2009), 
can be accessed to predict and score potential sumoylation sites for a given protein of interest. Of note, sumoylation can also be reversibly regulated by desumoylating enzymes.

Early work focused on nuclear proteins. It is now appreciated that proteins in all subcellular compartments are subject to sumoylation, including synaptic proteins such as glutamate receptors (Scheschonka et al., 2007; Sen and Snyder, 2010). GluK6 is a SUMO substrate in rat hippocampal neurons (Martin et al., 2007). GluK6 sumoylation is required for agonist-evoked endocytosis of the receptor. Noticeably, GluK6 is sumoylated at the C-terminal K886 site (Martin et al., 2007), which is adjacent to I884 critical for binding and formation of a complex for GluK6 ubiquitination (Salinas et al., 2006). The proximity of two types of modifications implies possible crosstalk. mGluR8 is sumoylated at its C-terminal K882 site (Tang et al., 2005). Other group III mGluRs (mGluR4/6/7) and GluK7 may also undergo reliable sumoylation (Wilkinson et al., 2008).

A striatum-enriched small G-protein ras homolog enriched in striatum (Rhes) has recently been found to act as a physiological regulator of protein sumoylation (Subramaniam et al., 2010). Rhes-deleted mice exhibited marked and selective reduction of protein sumoylation in the striatum (Subramaniam et al., 2009). Rhes expression is regulated by dopamine signals. Dopamine depletion reduced its mRNA and protein expression in the rat striatum (Harrison and LaHoste, 2006; Harrison et al., 2008). However, dopamine stimulation by acute amphetamine did not alter Rhes mRNA levels in the striatum (Schwendt and McGinty, 2010).

At present, sumoylation in drug action almost represents an uncharted area. It is possible that sumoylation of synaptic proteins including glutamate receptors is regulated by drug exposure. Altered sumoylation may contribute to the regulation of striatal signaling and drug addiction.

\section{CONCLUSION}

Glutamate receptors have long been appreciated to be subject to various post-translational modifications. Extensive studies have established glutamate receptors as direct substrates of protein kinases for robust phosphorylation at serine, threonine, or tyrosine

\section{REFERENCES}

Ahmadian, G., Ju, W., Liu, L., Wyszynski, M., Lee, S. H., Dunah, A. W., Taghibiglou, C., Wang, Y., Lu, J., Wong, T.P., Sheng, M., and Wang, Y.T. (2004). Tyrosine phosphorylation of GluR2 is required for insulin-stimulated AMPA receptor endocytosis and LTD. EMBO J. 23, 1040-1050.

Airas, J. M., Beta, H., and El Far, O. (2001). PKC phosphorylation of a conserved serine residue in the C-terminus of group III metabotropic glutamate receptors inhibits calmodulin binding. FEBS Lett. 494, 60-63.

Alaluf, S., Mulvihill,E. R., and McIIhinney, R. A. (1995). The metabotropic glutamate receptor mGluR4, but not mGluR1 alpha, is palmitoylated when expressed in BHK cells. J. Neurochem. 64, 1548-1555.
Anderson, S. M., Famous, K. R., SadriVakili, G., Kumaresan, V., Schmidt, H. D., Bass, C. E., Terwilliger, E. F., Cha, J. H., and Pierce, R. C. (2008). CaMKII: a biochemical bridge linking accumbens dopamine and glutamate systems in cocaine seeking. Nat. Neurosci. 11, 344-353.

Ba, M., Kong, M., Yang, H., Ma, G., Lu, G., Chen, S., and Liu, Z. (2006). Changes in subcellular distribution and phosphorylation of GluR1 in lesioned striatum of 6-hydroxydopamine-lesioned and 1-dopa-treated rats. Neurochem. Res. 31, 1337-1347.

Bachtell, R. K., Choi, K. H., Simmons, D. L., Falcon, E., Monteggia, L. M., Neve, R. L., and Self, D. W. (2008). Role of GluR1 expression in nucleus accumbens neurons in cocaine sensitization and cocaine-seeking

residues. Such phosphorylation is important for regulating trafficking and function of modified receptors. Reversible palmitoylation also occurs to glutamate receptor cysteine residues, which like phosphorylation regulates expression and activity of the receptor. Ubiquitination and sumoylation at lysine residues are other types of glutamate receptor modifications. These modifications control degradation or endocytosis of surface receptors and thus adjust surface expression levels of modified receptors. All these types of modifications are regulated by cellular and synaptic signals. In response to psychostimulants, glutamate receptors in striatal neurons show marked and dynamic changes in phosphorylation and palmitoylation. Even though limited studies have been attempted at present, emerging evidence indicates the linkage between these protein modifications and persistent drug-related plasticity at both receptor and behavioral levels.

In addition to phosphorylation, palmitoylation, ubiquitination and sumoylation summarized in this review, other types of protein modification may be substantial for the regulation of glutamate receptors. These potential modifications include nitrosylation (cysteine), sulfhydration (cysteine), acetylation (lysine), etc. (Sen and Snyder, 2010). Recently, these modifications are appreciated to impact far more proteins than expected and could influence glutamate receptors or their adaptor proteins as prominently and efficiently as phosphorylation. Additionally, different modifications are thought to interact with each other, especially when modifications occur at the same or proximal sites. This could pair two different modifications as a reciprocal process, such as palmitoylation and nitrosylation on cysteines or ubiquitination and sumoylation on lysines. It is anticipated that modification biology will grow rapidly and more modification models on glutamate receptors will be characterized in vivo. This will ultimately inform glutamate receptor modifications as to their clinical relevance, and assist in our understanding the pathogenesis of psychiatric illnesses and in developing therapeutic agents for drug addiction.

\section{ACKNOWLEDGMENTS}

The work by the authors discussed in this article was supported by NIH R01 DA010355 and R01 MH061469.

behavior. Eur. J. Neurosci. 27 2229-2240.

Banke, T. G., Bowie, D., Lee, H. K., Huganir, R. L., Schousboe, A., and Traynelis, S. F. (2000). Control of GluR1 AMPA receptor function by cAMP-dependent protein kinase. $J$. Neurosci. 20, 89-102.

Barria, A., Derkach, V., and Soderling, T. (1997). Identification of the Ca2+/ calmodulin-dependent protein kinase II regulatory phosphorylation site in the $\alpha$-amino-3-hydroxyl-5-methyl-4isoxazole-propionate-type glutamate receptor.J.Biol. Chem.272,32727-32730.

Bernard, V., Somogyi, P., and Bolam, J. P. (1997). Cellular, subcellular, and subsynaptic distribution of AMPAtype glutamate receptor subunits in the neostriatum of the rat. J. Neurosci. 17, 819-833.
Bingol, B., and Schuman, E. M. (2004). A proteasome-sensitive connection between PSD-95 and GluR1 endocytosis. Neuropharmacology 47,755-763.

Bird, M. K., and Lawrence, A. J. (2009). Group I metabotropic glutamate receptors: involvement in drugseeking and drug-induced plasticity. Curr. Mol. Pharmacol. 2, 83-94.

Boehm, J., Kang, M. G., Johnson, R. C. Esteban, J., Huganir, R. L., and Malinow, R. (2006). Synaptic incorporation of AMPA receptors during LTP is controlled by a PKC phosphorylation site on GluR1. Neuron 51, 213-225.

Boudreau, A. C., and Wolf, M. E. (2005). Behavioral sensitization to cocaine is associated with increased AMPA receptor surface expression in the nucleus accumbens. J. Neurosci. 25, 9144-9151. 
Bowers, M. S., Chen, B. T., and Bonci, A. (2010). AMPA receptor synaptic plasticity induced by psychostimulants: the past, present, and therapeutic future. Neuron 67, 11-24.

Cai, Z., Saugstad, J. A., Sorensen, S. D., Ciombor, K. J., Zhang, C., Schaffhauser, H., Hubalek, F., Pohl, J., Duvoisin, R. M., and Conn, P. J. (2001). Cyclic AMP-dependent protein kinase phosphorylates group III metabotropic glutamate receptors and inhibits their function as presynaptic receptors. J. Neurochem. 78, 756-766.

Carvalho, A. L., Duarte, C. B., and Carvalho, A. P. (2000). Regulation of AMPA receptors by phosphorylation. Neurochem. Res. 25, 1245-1255.

Cha, X. Y., Pierce, R. C., Kalivas, P. W., and Mackler, S. A. (1997). NAC-1, a rat brain mRNA, is increased in the nucleus accumbens three weeks after chronic cocaine self-administration. J. Neurosci. 17, 6864-6871.

Chao, S. Z., Lu, W., Lee, H. K., Huganir, R. L., and Wolf, M. E. (2002). D(1) dopamine receptor stimulation increases GluR1 phosphorylation in postnatal nucleus accumbens cultures. J. Neurochem. 81, 984-992.

Chen, B. S., Braud, S., Badger, J. D. II, Isaac, J. T., and Roche, K. W. (2006). Regulation of NR1/NR2C NMDA receptors by phosphorylation. J. Biol. Chem. 281, 16583-16590.

Chen, B. S., and Roche, K. W. (2009). Growth factor-dependent trafficking of cerebellar NMDA receptors via protein kinase B/Akt phosphorylation of NR2C. Neuron 62, 471-478.

Chen, H., and Manev, H. (2010). Effects of minocycline on cocaine sensitization and phosphorylation of GluR1 receptors in 5-lipoxygenase deficient mice. Neuropharmacology. PMID: 20868701. [Epub ahead of print].

Chen, Q., Veenman, C. L., and Reiner, A. (1996). Cellular expression of ionotropic glutamate receptor subunits on specific striatal neuron types and its implication for striatal vulnerability in glutamate receptor-mediated excitotoxicity. Neuroscience 73, 715-731.

Chen, Q., Zhu, X., Zhang, Y., Wetsel, W. E., Lee, T. H., and Zhang, X. (2010). Integrin-linked kinase is involved in cocaine sensitization by regulating PSD-95 and synapsin I expression and GluR1 Ser845 phosphorylation. J. Mol. Neurosci. 40, 284-294.

Chung, H. J., Xia, J., Scannevin, R. H., Zhang, X., and Huganir, R. L. (2000). Phosphorylation of the AMPA receptor subunit GluR2 differentially regulates its interaction with PDZ domain-containing proteins. J. Neurosci. 20, 7258-7267.

Colledge, M., Snyder, E. M., Crozier, R. A., Soderling, J. A., Jin, Y., Langeberg,
L. K., Lu, H., Bear, M. F., and Scott, J. D. (2003). Ubiquitination regulates PSD-95 degradation and AMPA receptor surface expression. Neuron 40, 595-607.

Conn, P. J., and Pin, J. P. (1997). Pharmacology and functions of metabotropic glutamate receptors. Annu. Rev. Pharmacol. Toxicol. 37, 205-237.

Conrad, K. L., Tseng, K. Y., Uejima, J. L., Reimers, J. M., Heng, L. J., Shaham, Y., Marinelli, M., and Wolf, M. E. (2008). Formation of accumbens GluR2lacking AMPA receptors mediates incubation of cocaine craving. Nature 454, 118-121.

Cull-Candy, S., Brickley, S., and Farrant, M. (2001). NMDA receptor subunits: diversity, development and disease. Curr. Opin. Neurobiol. 11, 327-335.

Delawary, M., Tezuka, T., Kiyama, Y. Yokoyama, K., Inoue, T., Hattori, S., Hashimoto, R., Umemori, H., Manabe, T., Yamamoto, T., and Nakazawa, T. (2010). NMDAR2B tyrosine phosphorylation regulates anxiety-like behavior and CRF expression in the amygdala. Mol. Brain 3, 37.

Delgado, J. Y., Coba, M., Anderson, C. N. Thompson, K. R., Gray, E. E., Heusner, C. L., Martin, K. C., Grant, S. G., and O’Dell, T. J. (2007). NMDA receptor activation dephosphorylates AMPA receptor glutamate receptor 1 subunits at threonine 840. J. Neurosci. 27, 13210-13221.

Derkach, V., Barria, A., and Soderling, T. R. (1999). Ca2+/calmodulin-kinase II enhances channel conductance of alpha-amino-3-hydroxy-5-methyl-4isoxazolepropionate type glutamate receptors. Proc. Natl. Acad. Sci. U.S.A. 96, 3269-3274.

Dingledine, R., Borges, K., Bowie, D., and Traynelis, S. F. (1999). The glutamate receptor ion channels. Pharmacol. Rev. 51, 7-61.

Dudman, J.T., Eaton, M.E., Rajadhyaksha, A., Macias, W., Taher, M., Barczak, A., Kameyama, K., Huganir, R., and Konradi, C. (2003). Dopamine D1 receptors mediate CREB phosphorylation via phosphorylation of the NMDA receptor at Ser897-NR1. J. Neurochem. 87, 922-934.

Dunah, A. W., Sirianni, A. C., Fienberg, A. A., Bastia, E., Schwarzschild, M.A., and Standaert, D. G. (2004). Dopamine D1-dependent trafficking of striatal $\mathrm{N}$-methyl-D-aspartate glutamate receptors requires Fyn protein tyrosine kinase but not DARPP-32. Mol. Pharmacol. 65, 121-129.

Dunah,A.W., and Standaert, D. G. (2001). Dopamine D1 receptor-dependent trafficking of striatal NMDA glutamate receptors to the postsynaptic membrane. J. Neurosci.21,5546-5558.
Dunah,A. W., and Standaert, D. G. (2003). Subcellular segregation of distinct heteromeric NMDA glutamate receptors in the striatum. J. Neurochem. 85 935-943.

Dunah, A. W., Wang, Y., Yasuda, R. P. Kameyama, K., Huganir, R. L., Wolfe, B. B., and Standaert, D. G. (2000) Alterations in subunit expression, composition, and phosphorylation of striatal $\mathrm{N}$-methyl-D-aspartate glutamate receptors in a rat 6-hydroxydopamine model of Parkinson's disease. Mol. Pharmacol. 57, 342-352.

Edwards, S., Graham, D. L., Bachtell, R. K. and Self, D.W. (2007). Region-specific tolerance to cocaine-regulated CAMPdependent protein phosphorylation following chronic self-administration. Eur. J. Neurosci. 25, 2201-2213.

Edwards, S., Graham, D. L., Whisler K. N., and Self, D. W. (2009). Phosphorylation of GluR1, ERK, and CREB during spontaneous withdrawa from chronic heroin self-administration. Synapse 63, 224-235.

Ehlers, M. D. (2003).Activity level controls postsynaptic composition and signaling via the ubiquitin-proteasome system. Nat. Neurosci. 6, 231-242.

El-Husseini, A.-D., and Bredt, D. S. (2002) Protein palmitoylation: a regulator of neuronal development and function. Nat. Rev. Neurosci. 3, 791-802.

Estaban, J. A., Shi, H., Wilson, C., Nuriya, M., Huganir, R. L., and Malinow, R. (2003). PKA phosphorylation of AMPA receptor subunits controls synaptic trafficking underlying plasticity. Nat. Neurosci. 6, 136-143.

Famous, K. R., Kumaresan, V., SadriVakili, G., Schmidt, H. D., Mierke, D. F., Cha, J. H., and Pierce, R. C. (2008) Phosphorylation-dependent trafficking of GluR2-containing AMPA receptors in the nucleus accumbens plays a critical role in the reinstatement of cocaine seeking. J. Neurosci. 28, 11061-11070.

Fox, C. J., Russell, K., Titterness, A. K. Wang, Y. T., and Christie, B. R. (2007). Tyrosine phosphorylation of the GluR2 subunit is required for longterm depression of synaptic efficacy in young animals in vivo. Hippocampus 17, 600-605.

Francesconi, A., and Duvoisin, R. M. (2000). Opposing effects of protein kinase $\mathrm{C}$ and protein kinase $\mathrm{A}$ on metabotropic glutamate receptor signaling: selective desensitization of the inositol trisphosphate/Ca2+ pathway by phosphorylation of the receptor-G protein-coupling domain. Proc. Natl. Acad. Sci. U.S.A. 97, 6185-6190.

Geiss-Friedlander, R., and Melchior, F. (2007). Concepts in sumoylation: a decade on. Nat. Rev. Mol. Cell Biol. 8 947-956.
Gereau, R. W. IV, and Heinemann, S. F. (1998). Role of protein kinase C phosphorylation in rapid desensitization of metabotropic glutamate receptor 5. Neuron 20, 143-151.

Goebel-Goody, S. M., Davies, K. D., Alvestad Linger, R. M., Freund, R. K., and Browning, M. D. (2009). Phospho-regulation of synaptic and extrasynaptic $N$-methyl-D-aspartate receptors in adult hippocampal slices. Neuroscience 158, 1446-1459.

Guo, C., and Wolf, M. E. (2008). Dopamine receptors regulate NMDA receptor surface expression in prefrontal cortex neurons. J. Neurochem. 106 2489-2501.

Hakansson, K., Galdi, S., Hendrick, J., Snyder, G., Greengard, P., and Fisone, C. (2006). Regulation of phosphorylation of the GluR1 AMPA receptor by dopamine D2 receptors. J. Neurochem. 96, 482-488.

Hallett, P. J., Spoelgen, R., Hyman, B. T., Standaert, D. G., and Dunah, A. W. (2006). Dopamine D1 activation potentiates striatal NMDA receptors by tyrosine phosphorylation-dependent subunit trafficking. J. Neurosci. 26, 4690-4700.

Harrison, L. M., and LaHoste, G. J. (2006). Rhes, the Ras homolog enriched in striatum, is reduced under conditions of dopamine supersensitivity. Neuroscience 137, 483-492.

Harrison, L. M., LaHoste, G. J., and Ruskin, D. N. (2008). Ontogeny and dopaminergic regulation in brain of Ras homolog enriched in striatum (Rhes). Brain Res. 1245, 16-25.

Hayashi, T., and Huganir, R. L. (2004). Tyrosine phosphorylation and regulation of the AMPA receptor by SRC family tyrosine kinases. J. Neurosci. 24 6152-6160.

Hayashi, T., Rumbaugh, G., and Huganir, R. L. (2005). Differential regulation of AMPA receptor subunit trafficking by palmitoylation of two distinct sites. Neuron 47, 709-723.

Hayashi, T., Thomas, G. M., and Huganir, R. L. (2009). Dual palmitoylation of NR2 subunits regulates NMDA receptor trafficking. Neuron 64, 213-226.

Hemby, S. E., Tang, W., Muly, E. C., Kuhar, M. J., Howell, L., and Mash, D. C. (2005). Cocaine-induced alterations in nucleus accumbens ionotropic glutamate receptor subunits in human and non-human primates. J. Neurochem. 95, 1785-1793.

Heun, P. (2007). SUMOrganization of the nucleus. Curr. Opin. Cell Biol. 19, 350-355.

Hisatsune, C., Umemori, H., Inoue, T., Michikawa, T., Kohda, K., Mikoshiba, K., and Yamamoto, T. (1997). Phosphorylation-dependent regulation of $\mathrm{N}$-methyl-D-aspartate 
receptors by calmodulin. J. Biol. Chem. 272, 20805-20810.

Hyman, S. E., Malenka, R. C., and Nestler, E. J. (2006). Neural mechanisms of addiction: the role of reward-related learning and memory. Annu. Rev. Neurosci. 29, 565-598.

Jurd, R., Thornton, C., Wang, J., Luong, K., Phamluong, K., Kharazia, V., Gibb, S. L., and Ron, D. (2008). Mind bomb-2 is an E3 ligase that ubiquitinates the $N$-methyl-D-aspartate receptor NR2B subunit in a phosphorylationdependent manner. J. Biol. Chem. 283, 301-310.

Kalivas, P. W. (2009). The glutamate homeostasis hypothesis of addiction. Nat. Rev. Neurosci. 10, 561-572.

Kato, A., Rouach, N., Nicoll, R. A., and Bredt,D.S. (2005). Activity-dependent NMDA receptor degradation mediated by retrotranslocation and ubiquitination. Proc. Natl. Acad. Sci. U.S.A. 102, 5600-5605.

Kawabata, S., Tsutsumi, R., Kohara, A., Yamaguchi, T., Nakanishi, S., and Okada, M. (1996). Control of calcium oscillations by phosphorylation of metabotropic glutamate receptors. Nature 383, 89-92.

Kim, S. M., Ahn, S. M., Go, B. S., Wang, J. Q., and Choe, E.S. (2009). Alterations in AMPA receptor phosphorylation in the rat striatum following acute and repeated cocaine administration. Neuroscience 163, 618-626.

Kim, C. H., Braud, S., Isaac, J. T., and Roche, K. W. (2005). Protein kinase C phosphorylation of the metabotropic glutamate receptor mGluR5 on Serine 839 regulates $\mathrm{Ca} 2+$ oscillations. J. Biol. Chem. 280, 25409-25415.

Kim, C. H., Lee, J., Lee, J. Y., and Roche, K.W. (2008). Metabotropic glutamate receptors: phosphorylation and receptor signaling. J. Neurosci. Res. 86, 1-10.

Landwehrmeyer, G. B., Standaert, D. G., Testa, C. M., Penny, J. B. Jr., and Young, A. B. (1995). NMDA receptor subunit mRNA expression by projection neurons and interneurons in rat striatum. J. Neurosci. 15, 5297-5307.

Lau, L. F., and Huganir, R. L. (1995). Differential tyrosine phosphorylation of $N$-methyl-D-aspartate receptor subunits. J. Biol. Chem. 270, 20036-20041.

Li, B., Devidze, N., Barengolts, D., Prostak, N., Sphicas, E., Apicella, A. J., Malinow, R., and Emamian, E. S. (2009). NMDA receptor phosphorylation at a site affected in schizophrenia controls synaptic and behavioral plasticity. J. Neurosci. 29, 11965-11972.

Liao, G. Y., Wagner, D. A., Hsu, M. H., and Leonard, J. P. (2001). Evidence for direct protein kinase-C mediated modulation of $N$-methyl-D-aspartate receptor current. Mol. Pharmacol. 59, 960-964.
Liu, X. Y., Chu, X. P., Mao, L. M., Wang, M., Lan, H. X., Li, M. H., Zhang, G. C., Parelkar, N. K., Fibuch, E. E., Haines, M., Neve, K. A., Liu, F., Xiong, Z. G., and Wang, J.Q. (2006). Modulation of D2R-NR2B interactions in response to cocaine. Neuron 52, 897-909.

Liu, Z., Mao, L., Parelkar, N. K., Tang, Q., Samdani, S., and Wang, J. Q. (2004). Distinct expression of phosphorylated $N$-methyl-D-aspartate receptor NR1subunits by projection neurons and interneurons in the striatum of normal and amphetamine-treated rats. J. Comp. Neurol. 474, 393-406.

Loftis, J. M., and Janowsky, A. (2002). Cocaine treatment- and withdrawalinduced alterations in the expression and serine phosphorylation of the NR1 NMDA receptor subunit. Psychopharmacology 164, 349-359.

Mackler, S. A., Korutla, L., Cha, X. Y., Koebbe, M. J., Fournier, K. M., Bowers, M.S., and Kalivas, P.W. (2000). NAC-1 is a brain POZ/BTB protein that can prevent cocaine-induced sensitization in the rat. J. Neurosci. 20, 6210-6217.

Mammen, A. L., Kameyama, K., Roche, K. W., and Huganir, R. L. (1997). Phosphorylation of the alphaamino-3-hydroxy-5-methylisoxazole4-propionic acid receptor GluR1 subunit by calcium/calmodulindependent kinase II. J. Biol. Chem. 272, 32528-32533.

Mangiavacchi, S., and Wolf, M. E. (2004) D1 dopamine receptor stimulation increases the rate of AMPA receptor insertion onto the surface of cultured nucleus accumbens neurons through a pathway dependent on protein kinase A. J. Neurochem. 88, 1261-1271.

Mao, L. M., Liu, X. Y., Zhang, G.C., Chu, X. P., Fibuch, E. E., Wang, L. S., Liu, Z., and Wang, J. Q. (2008). Phosphorylation of group I metabotropic glutamate receptors (mGluR1/5) in vitro and in vivo. Neuropharmacology 55, 403-408.

Mao, L. M., Wang, W., Chu, X. P., Zhang, G. C., Liu, X. Y., Yang, Y. J., Haines, M., Papasian, C. J., Fibuch, E. E., Buch, S., Chen, J. G., and Wang, J. Q. (2009). Stability of surface NMDA receptors controls synaptic and behavioral adaptations to amphetamine. Nat. Neurosci. 12, 602-610.

Martin, L. J., Blackstone, C. D., Huganir, R. L., and Price, D. L. (1993). The striatal mosaic in primates: striosomes and matrix are differentially enriched in ionotropic glutamate receptor subunits. J. Neurosci. 13, 782-792.

Martin, S., Nishimune, A., Mellor, J. R., and Henley, J. M. (2007). SUMOylation regulates kainite-receptor-mediated synaptic transmission. Nature 447 , 321-325.

Mattson, B. J., Bossert, J. M., Simmons, D. E., Nozaki, N., Nagarkar, D., Kreuter, J.
D., and Hope, B. T. (2005). Cocaineinduced CREB phosphorylation in nucleus accumbens of cocaine-sensitized rats is enabled by enhanced activation of extracellular signal-related kinase, but not protein kinase A. J. Neurochem. 95, 1481-1494.

Medler, K. F., and Bruch, R. C. (1999). Protein kinase Cbeta and delta selectively phosphorylate odorant and metabotropic glutamate receptors. Chem. Senses 24, 295-299.

Menegoz, M., Lau, L. F., Herve, D., Huganir, R. L., and Girault, J. A. (1995). Tyrosine phosphorylation of NMDA receptor in rat striatum effects of 6-OH-dopamine lesions. Neuroreport 7, 125-128.

Moriyoshi, K., Lijima, K., Fujii, H., Ito, H., Cho, Y., and Nakanishi, S. (2004). Seven in absentia homolog $1 \mathrm{~A}$ mediates ubiquitination and degradation of group 1 metabotropic glutamate receptors. Proc. Natl. Acad. Sci. U.S.A. 101, 8614-8619.

Moussawi, K., and Kalivas, P. W. (2010). Group II metabotropic glutamate receptors (mGlu2/3) in drug addiction. Eur. J. Pharmacol. 639, 115-122.

Nakazawa, T., Komai, S., Tezuka, T. Hisatsune, C., Umemori, H., Semba, K., Mishina, M., Manabe, T., and Yamamoto, T.(2001). Characterization of Fyn-mediated tyrosine phosphorylation sites on GluR epsilon 2 (NR2B) subunit of the $N$-methyl-D-aspartate receptor. J. Biol. Chem. 276, 693-699.

Noritake, J., Fukata, Y., Iwanaga, T., Naoki, H., Tsutsumi, R., Matsuda, N., Tani, H., Iwanari, H., Mochizuki, Y., Kodama, T., Matsuura, Y., Bredt, D., Hamakubo, T. and Fukata, M. (2009). Mobile DHHC palmitoylating enzyme mediates activity-sensitive synaptic targeting of PSD95. J. Cell Biol. 186, 147-160.

Omkumar, R. V., Melinda, O., Kiely, M. J., Rosenstein, A. J., Min, K. T., and Kennedy, M. B. (1996). Identification of a phosphorylation site for calcium/calmodulin-dependent protein kinase II in the NR2B subunit of the $N$-methyl-D-aspartate receptor. J. Biol. Chem. 271, 31670-31678.

Orlando, L. R., Ayala, R., Kett, L. R., Curley, A. A., Duffner, J., Bragg, D. C., Tsai, L. H., Dunah, A. W., and Young, A. B. (2009). Phosphorylation of the homer-binding domain of group I metabotropic glutamate receptors by cyclin-dependent kinase $5 . J$. Neurochem. 110, 557-569.

Orlando, L. R., Dunah, A. W., Standaert, D. G., and Young, A. B. (2002). Tyrosine phosphorylation of the metabotropic glutamate receptor mGluR5 in striatal neurons. Neuropharmacology 43 , 161-173.

Pickering, D. S., Taverna, F. A., Salter, M. W., and Hampson, D. R. (1995).
Palmitoylation of the GluR6 kainate receptor. Proc. Natl. Acad. Sci. U.S.A. 92, 12090-12094.

Planey, S. L., and Zacharias, D. A. (2009). Palmitoyl acyltransferases, their substrates, and novel assays to connect them. Mol. Mem. Biol. 26, 14-31.

Price, C. J., Kim, P., and Raymond, L. A. (1999). D1 dopamine receptorinduced cyclic AMP-dependent protein kinase phosphorylation and potentiation of striatal glutamate receptors. J. Neurochem. 73, 2441-2446.

Ratnam, J., and Teichberg, V. I. (2005). Neurofilament-light increases the cell surface expression of the $N$-methyl$\mathrm{D}$-aspartate receptor and prevents its ubiquitination. J. Neurochem. 92, 878-885.

Ren, J., Gao, X., Jin, C., Zhu, M., Wang, X., Shaw, A., Wen, L., Yao, X., and Xue, Y. (2009). Systematic study of protein sumoylation: development of a sitespecific predictor of SUMOsp 2.0 . Proteomics 9, 3409-3412.

Roche, K. W., O’Brien, R. J., Mammen, A. L., Bernhardt, J., and Huganir, R. L. (1996). Characterization of multiple phosphorylation sites on the AMPA receptor GluR1 subunit. Neuron 16 , 1179-1188.

Rostas, J. A., Brent, V. A., Voss, K., Errington, M. L., Bliss, T. V., and Gurd, J.W. (1996). Enhanced tyrosine phosphorylation of the $2 \mathrm{~B}$ subunit of the $N$-methyl-D-aspartate receptor in long-term potentiation. Proc. Natl. Acad. Sci. U.S.A. 93, 10452-10456.

Salinas, G. D., Blair, L. A., Needleman, L. A., Gonzales, J. D., Chen, Y., Li, M., Singer, J. D., and Marshall, J. (2006). Actinfilin is a Cul3 substrate adaptor, linking GluR6 kainate receptor subunits to the ubiquitin-proteasome pathway. J. Biol. Chem. 281, 40164-40173.

Sanz-Clemente, A., Matta, J.A., Isaac, J. T. and Roche, K.W. (2010). Casein kinase 2 regulates the NR2 subunit composition of synaptic NMDA receptors. Neuron 67, 984-996.

Schaffhauser, H., Cai, Z., Hubalek, F., Macek, T.A., Pohl, J., Murphy, T. J., and Conn, P. J. (2000). cAMP-dependent protein kinase inhibits mGluR2 coupling to G-proteins by direct receptor phosphorylation. J. Neurosci. 20, 5663-5670.

Scheschonka, A., Tang, Z., and Betz, H. (2007). Sumoylation in neurons: nuclear and synaptic roles? Trends Neurosci. 30, 85-91.

Schmidt, H. D., and Pierce, R. C. (2010). Cocaine-induced neuroadaptations in glutamate transmission: potential therapeutic targets for craving and addiction. Ann. N. Y. Acad. Sci. 1187, 35-75.

Schumann, J., Michaeli, A., and Yaka, R. (2009). Src-protein tyrosine kinases 
are required for cocaine-induced increase in the expression and function of the NMDA receptor in the ventral tegmental area. J. Neurochem. 108, 697-706.

Schwendt, M., and McGinty, J. F. (2010). Amphetamine up-regulates activator of G-protein signaling $1 \mathrm{mRNA}$ and protein levels in rat frontal cortex: the role of dopamine and glucocorticoid receptors. Neuroscience 168, 96-107.

Sen, N., and Snyder, S. H. (2010). Protein modifications involved in neurotransmitter and gasotransmitter signaling. Trends Neurosci. 33, 493-502.

Shen, H., Korutla, L., Champtiaux, N., Toda, S., LaLumiere, R., Vallone, J., Klugmann, M., Blendy, J. A., Mackler, S. A., and Kalivas, P. W. (2007). NAC1 regulates the recruitment of the proteasome complex into dendritic spines. J. Neurosci. 27, 8903-8913.

Snyder, G. L., Allen, P. B., Fienberg, A. A., Valle, C. G., Huganir, R. L., Nairn, A.C., and Greengard, P. (2000). Regulation of phosphorylation of the GluR1 AMPA receptor in the neostriatum by dopamine and psychostimulants in vivo. J. Neurosci. 20, 4480-4488.

Subramaniam, S., Mealer, R. G., Sixt, K. M., Barrow, R. K., Usiello, A., and Snyder, S. H. (2010). Rhes, a physiologic regulator of sumoylation, enhances cross-sumoylation between the basic sumoylation enzymes E1 and Ubc9. J. Biol. Chem. 285, 20428-20432.

Subramaniam, S., Sixt, K. M., Barrow, R., and Snyder, S. H. (2009). Rhes, a striatal specific protein, mediates mutanthuntingtin cytotoxicity. Science 324, 1327-1330.

Suh, Y. H., Pelkey, K. A., Lavezzari, G., Roche, P. A., Huganir, R. L., McBain, C. J., and Roche, K. W. (2008). Corequirement of PICK1 binding and PKC phosphorylation for stable surface expression of the metabotropic glutamate receptor mGluR7. Neuron $58,736-748$.

Sutton, M. A., Schmidt, E. F., Choi, K. H., Schad, C. A., Whisler, K., Simmons, D., Karanian, D. A., Monteggia, L. M., Neve, R. L., and Self, D. W. (2003). Extinction-induced up-regulation in AMPA receptors reduces cocaineseeking behavior. Nature 421, 70-75.

Suzuki, T., and Okumura-Noji, K. (1995). NMDA receptor subunits epsilon 1 (NR2A) and epsilon 2 (NR2B) are substrates for Fyn in the postsynaptic density fraction isolated from the rat brain. Biochem. Biophys. Res. Commun. 216, 582-588.

Swayze, R. D., Lise, M. F., Levinson, J. N., Phillips, A., and El-Husseini, A. (2004). Modulation of dopamine mediated phosphorylation of AMPA receptors by PSD-95 and AKAP79/150. Neuropharmacology 47, 764-778.

Swope, S. L., Moss, S. J., Raymond, L. A., and Huganir, R. L. (1999). Regulation of ligand-gated ion channels by protein phosphorylation. Adv. Second Messenger Phosphoprotein Res. 33, 49-78.

Tang, Z., EI Far, O., Betz, H., and Scheschonka, A. (2005). Pias 1 interaction and sumoylation of metabotropic glutamate receptor 8. J. Biol. Chem. 280, 38153-38159.

Taniguchi, S., Nakazawa, T., Tanimura, A., Kiyama, Y., Tezuka, T., Watabe, A. M., Katayama, N., Yokoyama, K., Inoue, T., Izumi-Nakaseko, H., Kakuta, S., Sudo, K., Iwakura, Y., Umemori, H., Inoue, T., Murphy, N. P., Hashimoto, K., Kano, M., Manabe, T., and Yamamoto, T. (2009). Involvement of NMDAR2A tyrosine phosphorylation in depression-related behaviour. EMBO J. 28, 3717-3729.

Tingley, W. G., Ehlers, M. D., Kameyama, K., Doherty, C., Ptak, J. B., Riley, C. T., and Huganir, R. L. (1997). Characterization of protein kinase $\mathrm{A}$ and protein kinase $\mathrm{C}$ phosphorylation of the $\mathrm{N}$-methyl-D-aspartate receptor NR1 subunit using phosphorylation site-specific antibodies. J. Biol. Chem. 272, 5157-5166.

Tovar, K. R., and Westbrook, G. L. (1999). The incorporation of NMDA receptors with a distinct subunit composition at nascent hippocampal synapses in vitro. J. Neurosci. 19, 4180-4188.

Tzschentke, T. M., and Schmidt, W. J. (2003). Glutamatergic mechanisms in addiction. Mol. Psychiatry 8, 373-382.

Uchino, M., Sakai, N., Kashiwagi, K., Shirai, Y., Shinohara, Y., Hirose, K., Lino, M., Yamamura, T., and Saito, N. (2004). Isoform-specific phosphorylation of metabotropic glutamate receptor 5 by protein kinase $\mathrm{C}(\mathrm{PKC})$ blocks $\mathrm{Ca} 2+$ oscillation and oscillatory translocation of Ca2+-dependent PKC. J. Biol. Chem. 279, 2254-2261.

Van Dolah, D. K., Mao, L. M., Shaffer, C., Guo, M. L., Fibuch, E. E., Chu, X.
P., Buch, S., and Wang, J. Q. (2011) Reversible palmitoylation regulates surface stability of AMPA receptors in the nucleus accumbens in response to cocaine in vivo. Biol. Psychiatry. doi: 10.1016/j.physletb.2003.10.071. [Epub ahead of print].

Wang, J., Lanfranco, M. F., Gibb, S. L., Yowell, Q.V., Carnicella, S., and Ron, D (2010). Long-lasting adaptations of the NR2B-containing NMDA receptors in the dorsomedial striatum play a crucial role in alcohol consumption and relapse. J. Neurosci. 30, 10187-10198.

Wang, J. Q., Liu, X., Zhang, G., Parelkar, N. K., Arora, A., Haines, M., Fibuch, E. E., and Mao, L. (2006). Phosphorylation of glutamate receptors: a potential mechanism for the regulation of receptor function and psychostimulant action. J. Neurosci. Res. 84 1621-1629.

Wang, Y. T., and Salter, M. W. (1994). Regulation of NMDA receptors by tyrosine kinases and phosphatases. Nature 369, 233-235.

Wilkinson, K. A., Nishimune, A., and Henley, J. M. (2008). Analysis of SUMO-1 modification of neuronal proteins containing consensus SUMOylation motifs. Neurosci. Lett. 436, 239-244.

Wu, H. Y., Hsu, F. C., Gleichman, A. J., Baconguis, I., Coulter,D.A., and Lynch, D. R. (2007). Fyn-mediated phosphorylation of NR2B Tyr-1336 controls calpain-mediated NR2B cleavage in neurons and heterologous systems. $J$. Biol. Chem. 282, 20075-20087.

Wu, K., Len, G. W., McAuliffe, G., Ma, C., Tai, J. P., Xu, F., and Black, I. B. (2004). Brain-derived neurotrophic factor acutely enhances tyrosine phosphorylation of the AMPA receptor subunit GluR1 via NMDA receptor-dependent mechanisms. Brain Res. Mol. Brain Res. $130,178-186$

Xi, Z. X., Ramamoorthy, S., Baker, D. A., Shen, H., Samuvel, D. J., and Kalivas, P. W. (2002). Modulation of group II metabotropic glutamate receptor signaling by chronic cocaine. J. Pharmacol. Exp. Ther. 303, 608-615.

Xu, F., Plummer, M. R., Len, G. W. Nakazawa, T., Yamamoto, T., Black, I. B., and Wu, K. (2006). Brain-derived neurotrophic factor rapidly increases NMDA receptor channel activity through Fyn-mediated phosphorylation. Brain Res. 1121, 22-34.
Xu, J., Litterst, C., Georgakopoulos, A., Zaganas, I., and Robakis, N. K. (2009). Peptide EphB2/CTF2 generated by the gamma-secretase processing of EphB2 receptor promotes tyrosine phosphorylation and cell surface localization of $\mathrm{N}$-methyl-D-aspartate receptors. J. Biol. Chem. 284, 27220-27228.

Yao, W. D., Gainetdinov, R. R., Arbuckle, M. I., Sotnikova, T. D., Cyr, M., Beaulieu, J. M., Torres, G. E., Grant, S. G., and Caron, M. G. (2004). Identification of PSD-95 as a regulator of dopamine-mediated synaptic and behavioral plasticity. Neuron 41, 625-638.

Yi, J.J., and Ehlers, M.D. (2005). Ubiquitin and protein turnover in synaptic function. Neuron 47, 629-632.

Zhang, X., Lee, T. H., Davidson, C., Lazarus, C., Wetsel, W. C., and Ellinwood, E. H. (2007). Reversal of cocaine-induced behavioral sensitization and associated phosphorylation of the NR2B and GluR1 subunits of the NMDA and AMPA receptors. Neuropsychopharmacology 32, 377-387.

Zhao, J. (2007). Sumoylation regulates diverse biological processes. Cell. Mol. Life Sci. 64, 3017-3033.

Zheng, F., Gingrich, M. B., Traynelis, S. F., and Conn, P. J. (1998). Tyrosine kinase potentiates NMDA receptor currents by reducing tonic zinc inhibition. Nat. Neurosci. 1, 185-191.

Conflict of Interest Statement: The authors declare that the research was conducted in the absence of any commercial or financial relationships that could be construed as a potential conflict of interest.

Received: 18 January 2011; paper pending published: 07 February 2011; accepted: 03 March 2011; published online: 17 March 2011.

Citation: Mao L-M, Guo M-L, Jin D-Z, Fibuch EE, Choe ES and Wang JQ (2011) Post-translational modification biology of glutamate receptors and drug addiction. Front. Neuroanat. 5:19. doi: 10.3389/ fnana.2011.00019

Copyright $\odot 2011$ Mao, Guo, Jin, Fibuch, Choe and Wang. This is an open-access article subject to an exclusive license agreement between the authors and Frontiers Media SA, which permits unrestricted use, distribution, and reproduction in any medium, provided the original authors and source are credited. 